\title{
Pluralizm racjonalności i pluralistyczna krytyka imparcjalizmu
}

\begin{abstract}
The article aims to present and critically analyze one of the currents of thought within the framework of deliberative democracy. The main dispute that we identify in the framework of this theory is the dispute between the impartialist and pluralistic approach. The role of reason towards the phenomenon of pluralism is the subject of these discussions. The impartialists base their arguments above all on the idea of public reason, while pluralists deny its value to other values. It can therefore be concluded that this dispute consists in opposing the rationality of pluralism to the pluralism of rationality. In addition to analyzing the arguments of the pluralist approach, we also focus on the criticism of the impartialism that these positions have put forward. The article distinguishes three possible forms of pluralism: rationality of pluralism, plurality of rationality prima facie and plurality of rationality sensu proprio. This allows us to show the relationship between impartialism (rationality of pluralism) and pluralism (plurality of rationalities prima facie) and the plurality of pluralism proposed by the critics of impartiality (plurality of rationalities prima facie) with a specific form of pluralism (plurality of rationality sensu proprio). In addition, in the article we identify the directives which pluralists propose to take place of public
\end{abstract}

1 Łukasz Perlikowski, Zakład Edukacji Obronnej i Bezpieczeństwa Wewnętrznego, Wydział Nauk Humanistycznych i Społecznych, Państwowa Wyższa Szkoła Zawodowa w Płocku, Polska, lukaszperlikowski@gmail.com. 
reason. The pluralistic approach which we analyze in the text is presented by such authors as: Iris Marion Young, Seyla Benhabib, Chantal Mouffe, Amy Gutmann and Dennis Thompson. The impartialist tradition should be associated with John Rawles and his interpreters and critics such as Joshua Cohen and Brian Barry.

\section{Keywords:}

pluralism, rationality, impartialism, deliberative democracy, political philosophy

\section{WPROWADZENIE}

Celem artykułu jest przedstawienie i krytyczna analiza jednego z dwóch głównych podejść filozoficzno-politycznych, które występują w ramach dyskusji o demokracji deliberatywnej. Główny spór, jaki dostrzegamy w debatach o kształcie nowoczesnej demokracji deliberatywnej ma miejsce między zwolennikami imparcjalizmu, czyli takiego podejścia do pluralizmu, które za zasadę porządkującą przyjmuje rozum publiczny, a zwolennikami podejścia radykalnie pluralistycznego. Pierwsze z wymienionych stanowisk odznacza się poszukiwaniem racjonalności pluralizmu, podczas gdy drugie głosi pluralizm różnych typów racjonalności.

Współcześnie dostrzega się tendencję do ujmowania rzeczywistości społeczeństw liberalnych demokracji jako przestrzeni różnych, lokalnych racjonalności. Gianni Vattimo postuluje możliwie najszerzej zakrojoną emancypację stanowisk światopoglądowych promujących rozmaite style życia. W kontekście racjonalności pisze o tym w następujący sposób: „Wraz z upadkiem idei swego rodzaju centralnej racjonalności historii świat powszechnej komunikacji eksploduje mnogością „lokalnych racjonalności” - mniejszości etnicznych, seksualnych, religijnych, kulturowych i estetycznych - które dochodząc do głosu zaczynają mówić we własnym imieniu” (Vattimo, 2006, s. 22). Ta predylekcja do wyzwolenia mnogości dyskursów jest podzielana przez większość autorów, którzy nie dostrzegają możliwości istnienia nowoczesnej demokracji bez pluralizmu racjonalności. Najważniejsze pytanie, jakie pojawia się w tym kontekście, dotyczy politycznego statusu takich projektów. Jaka jest rola władzy w świecie powszechnych swobód i dowolności? Pytanie to ma dla nas zasadnicze znaczenie. Dostrzegamy bowiem dwie możliwości w porządku analitycznym naszego wywodu - albo „pluralizm racjonalności” jest kolejnym typem racjonalności oraz istnieją dyrektywy argumentacji pluralistycznej i matryca argumentacji; albo pluralizm racjonalności jest 
faktycznie nurtem postulującym wolne interakcje stanowisk i koegzystowanie w sferze publicznej różnych, często sprzecznych ze sobą pozycji i systemów aksjologicznych. Wtedy jednak mówić możemy o intelektualnej wolności myśli, lecz nie o porządku politycznym. Jeśli mielibyśmy wskazać miejsce, w którym pluralizm jest zjawiskiem pożądanym, to byłby to np. uniwersytet, na którym myśli są uwolnione i tworzą swój własny porządek w specjalnie do tego celu wypreparowanych warunkach. Przyjrzyjmy się jednak politycznym aspektom i możliwym formom pluralizmu.

\section{FORMA PLURALIZMU}

By wykazać analitycznie możliwości funkcjonowania pluralizmu należy odwołać się do Roberta Dahla, który przedstawia możliwe konfiguracje w następujący sposób: „Tak więc obywatel może (1) dążyć do wspólnego dobra i zgadzać się na czym ono polega; (2) dążyć i nie zgadzać się; (3) zgadzać się, ale nie dążyć; (4) nie dążyć i nie zgadzać się” (Dahl, 1995, s. 399). Podział ten Dahl komentuje następująco: „Jeśli pojęcie cnoty obywatelskiej oraz wspólnego dobra dotyczyć mają świata nowożytnego, to odnosić je musimy do bardzo dużych społeczności demokratycznych, to jest do poliarchii i właściwego im pluralizmu” (Dahl, 1995, s. 400-401). Możemy zatem stwierdzić, iż w świetle naszej analizy racjonalność pluralizmu (imparcjalizm) związana jest z postawą obywatelską, wedle której obywatele zgadzają się co do dobra wspólnego, ale dążą do różnych celów przez siebie wyznaczonych i w tym właśnie upatrują wspólnego interesu. Jest to pierwsza spośród opcji wyznaczonych przez Dahla. Oznacza to, iż w istocie tworzą liberalną wspólnotę obywateli, którzy żyją w społeczeństwach kształtowanych przez tradycję liberalną i nie roszczą sobie prawa do uniwersalizmu. Jak zauważa Andrzej Szahaj:

„[...] liberalizm może uznać słuszność pewnych idei komunitarystycznych, starać się je zasymilować lub też odkryć w sobie ich ukrytą obecność. To, czego nie może uczynić, to zgoda na ograniczenie wolności wyboru «dobrego życia», która byłaby wynikiem uznania jakiejś doktryny światopoglądowej czy filozoficznej za na tyle lepszą od innych, że wprost nadającą się do urzędowego urządzenia ludzkiego życia we wszystkich jego wymiarach, do wykorzystania kryterium większości, aby ograniczać prawa wspólnot mniejszościowych do rezygnacji z wolności podstawowych. Krótko mówiąc to, czego nie może uczynić liberalizm, to przystać na rządy jakiejś formy fundamentalizmu politycznego" (Szahaj, 2000, s. 201). 
Wspólnota liberalna może więc zgadzać się co do tego, że dobrem wspólnym jej członków jest neutralne światopoglądowo państwo demokratyczne, które zapewnia pluralistyczną koegzystencję na rozumnych warunkach.

Pluralizm racjonalności oznaczałby natomiast postawę, która polega na braku zgody co do fundamentalnych zasad konstytuujących ład państwowy. To znaczy, że obywatele nie zgadzają się co do zasad dobra wspólnego, ale dążą do niego. Niezgoda jest zatem głównym elementem, który napędza dynamikę dyskursu publicznego. Będzie to aspekt widoczny u wszystkich autorów, którzy dają teoretyczne podwaliny podejścia pluralistycznego w demokracji deliberatywnej, a wśród nich znajdziemy między innymi: Iris Marion Young, Seylę Benhabib, Amy Gutman, Dennisa Thompsona oraz Chantal Mouffe. Wszyscy wyżej wymienieni podkreślają znaczenie niezgody i różnicy w kształtowania autentycznie demokratycznego i pluralistycznego ustroju.

W ramach uwag wstępnych do badania pluralizmu warto wskazać na zasadniczą oś sporów, w której autorzy będą się poruszać, czyli oś pluralizm-fundamentalizm. Na kwestię tę wskazywał już Józef Tischner w słowach:

\begin{abstract}
„Na tym przykładzie widzimy, czym jest pluralizm. Jest wielością w jedności, jednością w różnorodności. Uznając konieczność różnic, tworzy się jedność. Możemy powiedzieć: pluralizm polega na tym, że ludzie nawzajem uznają swoje prawa do różnic [...] Fundamentalizm pojęty jako negacja pluralizmu łączy się ściśle z pragnieniem władzy i używaniem przemocy. Jak inaczej bowiem zmusić człowieka do tego, by się wyrzekł swoich doświadczeń, a uznał moje? Jak go przekonać, że mój rozum jest miarą prawdy?” (Tischner, 1993, s. 151).
\end{abstract}

Dostrzegamy w tym fragmencie pewną dyrektywę pluralizmu, a mianowicie oderwanie od fundamentalnych podstaw i utrzymanie prymatu różnicy. Różnica ma być czymś konstytuującym ład pluralistyczny, stąd należy ją za wszelką cenę zachować. Odmienność wymaga ciągłego podkreślania swojej roli jako zaczynu pluralizmu. Kategoria rozumu, pojmowana swoiście jako mój rozum jest miarq prawdy, ma być marginalizowana na rzecz kategorii budujących różnicę. Te kategorie to uczucia, doświadczenia, sentymenty, potrzeba artykulacji, ale również potrzeba uznania. Przede wszystkim uznania swojej tożsamości jako równoprawnej z wszystkimi innymi tożsamościami, które wykształcają się na podstawie różnicy. Ponadto takie przyjęcie kategorii rozumu jako wroga pluralizmu zawiera pewne błędne założenie. Otóż rozum ma ze swej istoty charakter kolektywny. Widać to przede wszystkim na przykładzie hipotezy języka prywatnego według Ludwika 
Wittgensteina oraz wspólnotowego wymiaru rozumności według Gadamera, ale również u myślicieli związanych stricte z filozofią polityki, jak John Rawls i cała tradycja teorii rozumu publicznego. Pluraliści w rozumie będą widzieć wroga pluralizmu i to jest fundamentalna kwestia w ramach tego stanowiska. Pluralizm racjonalności będzie sprowadzał rozum na niższy poziom i ustanawiał go jako jeden z wielu równoprawnych instrumentów.

W innym miejscu Tischner pisze: „Z respektu dla różnorodności w sferze tego, co rozumne, narodziła się fenomenologia. Bo o cóż chodzi? Najpierw, o co nie chodzi. Nie chodzi o odkrywanie racjonalności wzorcowej, zdolnej do pochłonięcia całej reszty. Chodzi o odkrycie racjonalności źródłowej, to znaczy takiej, od której zaczyna się dla nas doświadczenie wszelkiej innej racjonalności” (Tischner, 2001, s. 480). I to uwidacznia główny problem podejścia, które nazywamy pluralizmem racjonalności. Z jednej strony bowiem panuje sprzeciw wobec porządkowania wedle kryterium rozumu lub innego czynnika potencjalnie dyskryminującego, ponieważ nie ma porządku, który stawiałby na równi wszystkie obiekty w swoim zasięgu. Z drugiej natomiast strony to, że pluralizm musi być chroniony przed jego styranizowaniem, pociąga za sobą konieczność jakiegoś usystematyzowania przedmiotu tej obrony. Stąd argumentację Tischnera odbieramy jako mglistą. Istnieją według niej różne racjonalności, ale jest także racjonalność innego porządku i tylko dzięki niej możemy poznać wszystkie inne. Wydaje się zatem, że nie wszystkie racjonalności są równie, a jeśli przyjmiemy, iż rolą tej prymarnej racjonalności jest doświadczanie, to nie sposób nie zauważyć, iż perspektywa ta zagrożona jest mankamentem subiektywizmu. Choć egzegeza tak zawile opisanego pluralizmu jest wyjątkowo trudna, to spróbujemy sformułować płynący z tego wniosek w następujący sposób: każdy ma swój rozum i każdy ma swoje racjonalności, ale ten rozumu i te racjonalności, które nie są spolegliwe i nie sprzyjają uznaniu każdego stanowiska za pełnoprawne, są podejrzane i nie powinny być uznawane.

Tak zarysowana relacja pluralizmu do racjonalności skłania nas do wyróżnienia trzech form pluralizmu. Pierwszą jest rozumny pluralizm, gdzie racjonalność explicite jest czynnikiem nadrzędnym względem pluralizmu, a którego przykładem jest imparcjalizm. Tę formę nazwaliśmy na wstępie racjonalnością pluralizmu.

Druga możliwa forma polega na uwolnieniu różnych racjonalności spod jarzma rozumu. Wiązać to należy z pluralizmem racjonalności prima facie. Oznacza to, że postulowanie wielości i podkreślanie różnorodności ma tutaj na celu próbę podważenia rozumnego pluralizmu i wystąpienie przeciw rozumowi jako czynnikowi dyskryminującemu. 
Trzecia forma, jaką przyjąć może pluralizm w relacji do racjonalności, to autentyczny pluralizm racjonalności sensu proprio, który kojarzyć trzeba z podejściem anarchizmu metodologicznego. Anarchizm ten należy pojmować przede wszystkim w wymiarze teoretycznym. Jego głównym przedstawicielem jest Paul Feyerabend, który za naczelną zasadę przyjmuje anything goes, co można tłumaczyć jako: wszystko ujdzie, czy też za polskim tłumaczem: nic świętego. Zasada ta ściśle wiąże się z podejściem pluralistycznym, co autor wyraża wprost w słowach:

„[...] istnieje tylko jedna zasada, której bronić można we wszystkich okolicznościach i we wszystkich stadiach rozwoju ludzkości. Oto owa zasada: nic świętego. Tę abstrakcyjną zasadę należy obecnie zbadać i objaśnić w szczegółach [...] Szczegółowe przebadanie zasady «nic świętego» oznacza prześledzenie konsekwencji wynikających z «kontrreguł» - opozycyjnych względem znanych reguł postępowania badawczego [...] Naukowiec pragnący zmaksymalizować treść empiryczną głoszonych przez siebie poglądów i chcący zrozumieć je możliwie najdokładniej, musi więc uwzględnić inne poglądy, to znaczy, musi przyjąć metodologię pluralistyczną" (Feyerabned, 1996, s. 14-21).

Pluralizm racjonalności będzie więc swego rodzaju intencjonalnym chaosem, co sprawia, że posiada niski potencjał jako czynnik organizujący społeczeństwa lub jako głos w sferze publicznej. Podejście to jest natomiast charakterystyczne dla świata nauki i wyzwolonej myśli. Najkrócej rzecz ujmując: porządek pluralizmu racjonalności nie jest porządkiem politycznym.

Na tym etapie wywodu nie rozstrzygamy, czy przedstawiciele podejścia pluralistycznego w demokracji deliberatywnej są związani z pluralizmem racjonalności prima facie, czy pluralizmem racjonalności sensu proprio. Najpierw bowiem przedstawimy to podejście na przykładzie twórczości Iris Marion Young, Seyli Benhabib, Amy Gutmann i Dennisa Thompsona oraz Chantal Mouffe.

\section{PLURALIZM A INKLUZJA (IRIS MARION YOUNG)}

Iris Marion Young kojarzona jest przed wszystkim z feministyczną teorią społeczną, ale również z takimi tematami jak: fenomenologia gender, przemoc i opór, etyka i odpowiedzialność, demokracja i inkluzja oraz teoria sprawiedliwości (Ferguson, Nagel, 2009). O interesującym nas temacie, czyli krytyce imparcjalizmu, czytamy w książce pt. Justice and Politics of Difference (Young, 1990). Autorka wskazuje 
przede wszystkim na to, że główną zasadą imparcjalizmu jest zredukowanie różnic, a dokładniej: abstrahowanie od partykularności, kontekstu sytuacji, uczuć, afiliacji i punktów widzenia. Ale partykularności stale pozostają w mocy biorąc pod uwagę kontekst sytuacji społecznych. Imparcjalizm natomiast wprowadza sztywną dychotomię na to, co uniwersalne, i to, co partykularne, a co za tym idzie, na: publiczne i prywatne, rozum i namiętności etc. (Young, 1990, s. 97). Young wskazuje, iż rozum dąży zawsze do klasyfikowania bytów, wyznaczania granic danych kategorii i pozycjonowania obiektów wewnątrz lub na zewnątrz. Rozum w tym sensie jest więc z istoty swej narzędziem dyskryminacji i władzy. Taka koncepcja rozumu jest zatem nieodłącznym elementem teoretycznego dyskursu cywilizacji Zachodu.

Jako poplecznika swojej krytyki rozumu Young wybiera Jacquesa Derridę, który w swoich pracach dekonstruował dyskurs rozumu i wskazywał, że to, co rozum stara się opanować, nie wyczerpuje wszystkich możliwości. By nie wgłębiać się w myśl francuskiego postmodernisty, wskażmy jedynie na jego interpretację

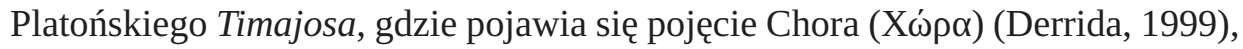
które ma oznaczać to, co daje miejsce, umiejscowienie, usytuowanie; coś co wychodzi poza klasyczne opozycje. Jeśli weźmiemy pod uwagę polis w jej granicach i to, co nazywane jest zagranicą, to chora jest tym, co leży pomiędzy polis a zagranicą. Derrida w ten sposób chce pokazać, że rzeczywiste różnicowanie dokonuje się poza opozycjami takimi jak: filozofowie-sofiści, mythos-logos etc. Szukanie możliwości konstytuowania się tożsamości przez różnicę będzie więc głównym wątkiem łączącym Derridę z Iris Marion Young.

Autorka krytykuje jednak nie tylko dyskurs rozumu, ale również logikę tożsamości. Wskazuje bowiem, że dochodzi do pewnego paradoksu, który polega na tym, iż w rzeczywistości dąży do redukcji pluralizmu. Young podkreśla, że logika tożsamości sprowadza różnicę do relacji z absolutnym innym, co zamiast prowadzić do pluralizmu i wyzwolenia, tworzy kolejną dychotomię wnętrza i zewnętrza (Young, 1990, s. 99).

Krytyka imparcjalizmu odbywa się również na zasadniczym poziomie, mianowicie Young twierdzi, że ideał bezstronności jest niemożliwy do zrealizowania:

„Ideał bezstronności jest idealistyczną fikcją. Niemożliwe jest przyjęcie nieusytuowanego moralnego punktu widzenia, a jeśli punkt widzenia jest usytuowany, wtedy nie może być uniwersalny, nie może stać z boku i pojmować wszystkie punkty widzenia. Niemożliwe jest przedstawianie racji do substancjalnych spraw moralnych bez rozumienia ich substancji, które zawsze presuponują pewien partykularny społeczny i historyczny kontekst; i gdzie 
ludzie nie mają motywacji do czynienia sądów moralnych i rozwiązywania moralnych dylematów, chyba że wyniki mają znaczenie oraz, że ktoś ma partykularny i namiętny interes w tym wyniku” (Young, 1990, s. 104).

Przyczyną, dla której autorka tak dogłębnie krytykuje imparcjalizm jest to, że dostrzega w nim funkcję ideologiczną. Jej zdaniem perspektywa oparta na bezstronnym decydowaniu służy legitymizacji niedemokratycznych, autorytarnych struktur podejmowania decyzji. Trzeba zatem zauważyć, że problem, na który wskazywaliśmy wcześniej, czyli relacja rozumu do rządów ludu, staje się w kontekście pluralizmu i demokracji deliberatywnej kwestią zasadniczą. Jest tak bowiem w istocie, że decyzje podjęte na podstawie rozumowania różnią się od decyzji podjętych w oparciu o wolę suwerennego ludu. Autorka wskazuje ponadto, że legitymacja oparta na bezstronności prowadzi do hierarchizowania procesu podejmowania decyzji oraz do uprzywilejowywania grup podejmujących tę decyzję. Imparcjalizm prowadzi więc do tyranii pozornie neutralnej biurokracji, która jest wyrazem rządów autorytarnych. Ma to związek przede wszystkim z naciskiem, jaki w ramach imparcjalistycznej demokracji deliberatywnej kładzie się na procedurę.

Postulaty Iris Marion Young, które mają zapewnić realny pluralizm oraz uniknięcie problemów, z jakimi boryka się stanowisko imparcjalistyczne, opierają się przede wszystkim na inkluzji. Czytamy o tym w książce wydanej dziesięć lat później pt. Inclusion and Democracy (Young, 2000). Autorka krytykuje model deliberatywny demokracji ze względu na to, iż jest on sam w sobie wykluczający, co spowodowane jest przez narzucenie ram dyskursu. Przedstawia ona kilka argumentów, między innymi „,argument uprzywilejowania”. Ułożenie schematu rozumowania od przesłanek do wniosków sprawia, że wykluczone są inne formy komunikacji, które mogłoby wygenerować wartościowe argumenty. Young zwraca uwagę, że posługuje się inną koncepcją rozumności, która wynika raczej z tradycji Habermasowskiej. Jej zdaniem bowiem:

„Bycie rozumnym w dyskusji oznacza bycie otwartym na słuchanie innych oraz gotowość poddania się ich wpływom i na artykułowanie własnych wrażeń celem uzyskania zgody lub zrozumienia. Chęć i możliwość bycia rozumnym w tym sensie leży u podstaw praktykowania działania komunikacyjnego jako takiego; tak długo jak ludzie rozmawiają, zmierzają do zrozumienia siebie nawzajem. Bycie rozumnym w tym sensie nie wymaga specjalnej edukacji czy treningu poza znaczącym pożądaniem kooperatywnych interakcji społecznych” (Young, 2000, s. 38). 
Ustalenie jednego rozumu, który ma stanowić instancję orzekania o słuszności argumentów zostaje zastąpione przez wolną komunikację. Przypomnijmy bowiem, że wedle ustaleń Habermasa wolnej komunikacji nie sposób narzucić siłą. Komunikacja wykształca się sama na drodze społecznych interakcji i działania komunikacyjnego jednostek i grup społecznych.

Inną ważną kwestią podniesioną przez Young jest to, że demokracja deliberatywna zakłada istnienie pewnych wspólnych założeń i wartości, które są podstawą dyskursu. Zwraca ona uwagę, iż w pluralistycznych społeczeństwach nie można znaleźć wspólnych założeń w obliczu wielu sytuacji i różnych kontekstów społecznych, z jakimi mamy do czynienia. W sytuacjach konfliktu i wobec potrzeby rozwiązywania kolektywnych problemów znaczący jest fakt, iż na każdym szczeblu polityki mamy do czynienia z wielokulturowością.

Young zauważa dwa główne podejścia w ramach teorii demokracji deliberatywnej. Pierwsze zakłada istnienie apriorycznych warunków debaty, drugie natomiast wybiera ustalenie takich wspólnych założeń jako cel debaty. Jedni więc uznają zgodę za coś pierwotnego, na bazie czego buduje się deliberację, inni z kolei uznają zgodę za cel deliberacji, który jest jej najwartościowszym osiągnięciem (Young, 2000, s. 40).

Autorka Inclusion and Democracy wskazuje na różnice społeczne jako potencjalne źródło demokratycznej komunikacji. Demokratyczna sfera publiczna powinna być w pełni inkluzywna względem wszystkich grup społecznych, ponieważ pluralizm perspektyw, które one proponują, zapewnia odzwierciedlenie obiektywnej rzeczywistości, w których funkcjonują razem. Ich wspólne interakcje konstytuują rozumienie wspólnego świata, w którym się znajdują. Young zwraca uwagę na epistemiczny walor pluralistycznych interakcji społecznych w słowach: „Konfrontacja z różnymi perspektywami, interesami i kulturowymi znaczeniami uczą każdą ze stron i odsłaniają dla nich ich własne doświadczenie jako perspektywiczne. Wysłuchiwanie tych asocjacji usytuowanych różnie ode mnie i moich bliskich uczy mnie jak moja sytuacja wygląda dla nich, w jakich relacji stoją dla innych w ich własnym odbiorze” (Young, 2000, s. 116).

Trzeba jednak jasno podkreślić, iż dla Iris Marion Young porządek priorytetów wygląda inaczej niż dla klasycznych autorów doktryny demokracji deliberatywnej. Uważa ona bowiem, i to wydaje się być kluczowym aspektem różnicującym podejście deliberatywne i podejście pluralistyczne, że celem nie jest usprawnienie deliberacji lub jej konkluzywność, ani zwiększenie jakości decyzji politycznych. Dla niej bowiem najważniejszą kwestią jest inkluzja (Young, 2000, s 119). „Zasadniczym celem demokratycznej dyskusji i podejmowania decyzji - pisze Iris Marion Young - powinno być promowanie sprawiedliwości w rozwiązywaniu 
problemu; ja również argumentuję, że ten cel wymaga inkluzji, nawet jeśli powoduje komplikacje i odsłania konflikty interesów, które mogą być rozwiązane jedynie przez zmianę strukturalnym relacji” (Young, 2000, s. 119). Trzeba wyraźnie podkreślić, iż jest to podejście skrajnie egalitarystyczne, które sprawiedliwość definiuje przez taki sam udział wszystkich stron w dyskusji. Dyskusja jest wartością samą w sobie. Odbywa się w sferze publicznej, a obecność w tej sferze samo przez siebie jest nobilitacją, którą powinna doznać każda z zainteresowanych stron. Głos wszystkich mniejszości musi być słyszany, brany pod uwagę bez względu na merytoryczny wkład w podejmowanie decyzji. Przez dokonywanie narracji opowiadającej o danym stanowisku, przez artykulację pragnień, odczuć, doświadczeń dane stanowisko przyczynia się do wkładu na rzecz stworzenia mozaiki społeczeństwa pluralistycznego, które jest wartością autoteliczną. Interakcje między podmiotami tego społeczeństwa mają sens, ponieważ przyczyniają się do wzrostu wiedzy, jakie stanowiska mają nawzajem o sobie oraz o całości systemu społecznego. Deliberacja jest więc instrumentem, który ma animować pluralizm racjonalności.

\section{PLURALIZM A RÓŻNICA (SEYLA BENHABIB)}

Inną autorką związaną z podejściem pluralistycznym, która ma istotny wkład w teorii społeczeństwa pluralistycznego, jest Seyla Benhabib. Jej głównym obiektem zainteresowań jest różnica i oparte na niej społeczeństwo różnorodne. Benhabib jest redaktorką tomu tekstów o tej tematyce pt. Democracy and Difference. Contesting the Boundaries of the Political (Benhabib, 1996), w którym swoje poglądy zaprezentowali prominentni teoreytcy nowoczesnej demokracji, w tym demokracji deliberatywnej. Pełniejszy wykład jej stanowiska znajdujemy jednak w pracy z 2002 roku pt. The Claims of Culture. Equality and Diversity in the Global Era (Benhabib, 2000), w którym kwestia demokracji deliberatywnej przedstawiona jest w kontekście multikulturowości (2000, s. 105-146). Autorka wychodzi od dwóch podejść do demokracji deliberatywnej, które zostały przez nas wcześniej zasygnalizowane, czyli od podejścia imparcjalistycznego, zwanego liberalnym egalitaryzmem (Brian Barry), oraz pluralistycznego (Iris Marion Young, Nancy Fraser). Benhabib zmierza w kierunku wyznaczonym przez drugie podejście z tym zastrzeżeniem, że w jej opinii „,...] niektóre praktyki i działania nie są właściwym przedmiotem kolektywnych akcji; jakkolwiek, myślę również, iż wszystkie praktyki i działania mogą stać się właściwymi przedmiotami dla publicznej dyskusji i ekspresji” (Benhabib, 2000, s. 120), co oznacza, że deliberacji 
jest w tym przypadku przeznaczona większa rola w animowaniu sfery publicznej. Zdaniem Seyli Benhabib model deliberatywny demokracji odstaje od zasadniczych problemów społecznych, ponieważ nie bierze pod uwagę zróżnicowania etnicznego społeczeństw pluralistycznych. Głębokie konflikty na tle etnicznym i narodowym nie są ujmowane w ramach demokracji deliberatywnej. Zasady, które dla sfery publicznej proponują multikulturowi pluraliści to przede wszystkim: 1) egalitarna wzajemność - przedstawiciele mniejszości muszą być traktowani na równi z przedstawicielami większości; 2) dobrowolne samoprzypisanie - jednostka nie może być automatycznie przypisywana do grupy kulturowej, religijnej etc., lecz jest to związane z aktem jej woli; 3) wolność do porzucenia asocjacji - jednostka powinna mieć możliwość zrezygnowania z wybranej przez siebie przynależności etnicznej, kulturowej, religijnej etc. (Behabib, 2000, s. 131-132).

Seyla Benhabib wprowadza istotne rozróżnienie w racjach przedstawianych w sferze publicznej. Wskazuje ona, że możemy mówić o syntaktyce i semantyce racji publicznych:

„Twierdzenie, że A jest racją do przyjęcia rozwiązania politycznego X lub prawa Y, mogłoby być zrównane z twierdzeniem, że „X lub Y są w najlepszym interesie wszystkich zainteresowanych równych moralnie i politycznie podmiotów. I możemy uzasadnić to twierdzenie, ponieważ ustanowiliśmy X lub Y w procesie publicznej deliberacji, w której wszyscy zainteresowani stosowali się do tych norm i polityki i brali w niej udział jako partycypujący w dyskursie. To jest syntaktyczna struktura publicznych racji w modelach demokracji deliberatywnej. Treść X i Y, tak jak istota argumentów i racji przedstawianych w dyskursach procesu ustanawiania takich wniosków, dotyczy semantyki racji” (2000, 140-141).

Ukazuje ona więc możliwość, w ramach semantyki racji publicznych, że mniejszości mogą przekonywać większość co do tworzenia ram demokracji deliberatywnej. Ma to wpłynąć rzecz jasna na zwiększenie pluralizmu. Istotna różnica w postulatach Young i Benhabib polega na tym, iż ta pierwsza sugeruje postawienie inkluzji najwyżej wśród pryncypiów społecznych, natomiast Benhabib skupia się emancypacji i równouprawnieniu konkretnych mniejszości przy jednoczesnym zachowaniu i podkreślaniu ich tożsamości. Inkluzywność i multikulturowość jawią nam się jako dwie odmienne wizje pluralizmu, które różnią się co do rozłożenia akcentów, a nie co do zasad pluralistycznego społeczeństwa demokracji liberalnej. 


\section{PLURALIZM AGONISTYCZNY (CHANTAL MOUFFE)}

W kontekście pluralistycznej koncepcji demokracji deliberatywnej nie sposób nie wspomnieć o teorii Chantal Mouffe, znanej przede wszystkim z książki opublikowanej wspólnie z Ernestem Laclau pt. Hegemony and Socialist Strategy. Towards a Radical Democratic Politics (Laclau, Mouffe, 1985). Generalnie rzecz ujmując, celem Mouffe jest wystąpienie przeciw miałkości liberalizmu jako ideologii, która miałaby rozwiązać wszelkie problem polityczne i doprowadzić do końca polityczności. Mouffe dokonuje kontrowersyjnego zabiegu, gdyż celem ataku na liberalizm za teoretyczną podstawę przyjmuje myśl Carla Schmitta kojarzonego z nurtami prawicowymi, a nie lewicowymi i liberalno-demokratycznymi. Przeformułowuje ona jednak pewne założenie antagonistyczne na agonistyczne. W swojej książce pt. Polityczność (Mouffe, 2005) wskazuje, że sposobem na przywrócenie polityczności jest powrót do kategorii wroga i przyjaciela, które Schmitt uważa za rdzeń polityczności (Shmitt, 2000, s. 191-250). Warto podkreślić, że rozróżnienie to odnosi się do wroga w sensie hostis, czyli wroga publicznego. Istnienie takiego wroga jest główną przyczyną powstania wspólnoty politycznej i tworzenia się tożsamości w odniesieniu do wroga właśnie. W koncepcji Schmittowskiej ma to więc głęboki charakter egzystencjalny. Powstaje zatem pytanie: jak można pogodzić twierdzenia Carla Schmitta z postulatami różnorodności i demokracji deliberatywnej, zwłaszcza że autor ten był zadeklarowanym wrogiem parlamentaryzmu jako takiego (Schmitt, 2000, s. 115-190)?

Otóż Chantal Mouffe postuluje dokonanie dość karkołomnego zabiegu polegającego na przedefiniowaniu wroga na rywala w publicznym agonie stanowisk politycznych. Jest to raczej trawestacja myśli Schmitta, niż właściwa interpretacja jego dzieła. Można by nawet stwierdzić, że teoria Chantal Mouffe jest jawnym zaprzeczeniem tez Pojęcia polityczności, a przyjęcie osoby Schmitta za teoretyczną inspirację stanowi raczej chwyt marketingowy w odniesieniu do rynku idei. Trudno bowiem utrzymywać powagę wymiaru egzystencjalnego polityczności, gdy działalność polityczna ma polegać głównie na uczestniczeniu w dyskursie o sprawach publicznych. Schmitt w swoich teoriach przede wszystkim dążył do uzasadnienia jedności państwowej, podczas gdy Mouffe za cel wybrała teoretyczną podbudowę demokratycznego państwa pluralistycznego. Niemiecki jurysta lokalizował pluralizm na zupełnie innym szczeblu, ponieważ wskazywał, że pluralistyczny ład istnieje w stosunkach międzynarodowych, gdzie mamy do czynienia z pluralizmem podmiotów politycznych. Jeśli mowa natomiast o sytuacji wewnątrz państwa, to polityczność i pluralizm jawią się nam wręcz jako czynniki przeciwstawne, 
ponieważ, jak wskazuje Schmitt: „polityczność oznacza właściwie wyłącznie stopień intensywności jakiejś jedności” (Schmitt, 2010, s. 77).

Chantal Mouffe krytykuje, generalnie rzecz ujmując, konsensualne podejście do demokracji, a w swoich pismach przedstawia apologię demokracji radykalnej, czyli opartej na agonistycznym pluralizmie (Mouffe, 2000). Swoją koncepcję autorka prezentuje w Agonistics. Thinking The World Politically (Mouffe, 2013), gdzie czytamy, że:

„Zasadniczą sprawą jest zatem to, jak ustanowić tę dystynkcję my-oni, która jest konstytutywna dla polityczności, w sposób, który jest kompatybilny z rozpoznaniem pluralizmu. Konflikt w liberalnych społeczeństwach demokratycznych nie może i nie powinien powstawać, stąd specyfikacja liberalnej demokracji polega na rozpoznaniu i uzasadnieniu konfliktu. Liberalna polityka demokratyczna wymaga, by nie postrzegać innych jako przeciwników do zniszczenia, lecz jako adwersarzy, których idee mogą być zwalczane, ale którzy mają prawo bronić tych idei. Inaczej rzecz ujmując, to co jest ważne, to to, że konflikt nie przybiera formy antagonizmu (bitwy pomiędzy przeciwnikami), lecz agonizmu (starcia pomiędzy adwersarzami)” (2013, s. 15).

W związku z dość enigmatycznym sposobem zniesienia antagonizmów na rzecz agonizmu, Mouffe wskazuje, że celem wszelkich tego typu konstruktów teoretycznych jest uzasadnienie pluralizmu w ramach ustroju demokratycznego:

„W pluralistycznych demokracjach, niezgoda co do interpretowania wspólnych etyczno-politycznych zasad jest nie tylko uzasadniona, lecz konieczna. Pozwalają one na występowanie różnych form obywatelskiej identyfikacji i są przedmiotem demokratycznej polityki. Gdy agonistyczna dynamika pluralizmu jest utrudniona z powodu braku demokratycznych form identyfikacji, to namiętności nie mogą znaleźć demokratycznego ujścia. Podstawą jest zatem ułożenie różnych form polityki artykułowanej wokół esencjonalnych tożsamości narodowych, religijnych, etnicznych i multiplikacja konfrontacji wokół nienegocjowalnych wartości moralnych, ze wszystkimi manifestacjami przemocy, które takie konfrontacje pociągają za sobą” (Mouffe, 2013, s. 14).

Mouffe zarzuca deliberatywnym modelom demokracji przede wszystkim to, że nie mogą obyć się bez wykluczenia. Prowadzi to, zdaniem autorki, do kryzysu tożsamości i pluralizmu, a co za tym idzie, do właściwej marginalizacji sfery politycznej. Alteratywą dla deliberacji ma być model agonistyczny, w którym 
Mouffe postrzega remedium na problemy polityczne współczesnego świata (Mouffe, 1999). Kolejny raz mamy więc do czynienia ze sporem, którego formą pierwotną jest opozycja pluralizm-imparcjalizm. Przyjrzyjmy się jednak jeszcze jednemu przejawowi pluralistycznej krytyki demokracji deliberatywnej opartej na bezstronności.

\section{ROZUMNA NIEZGODA (AMY GUTMANN I DENNIS THOMPSON)}

Amy Gutmann i Dennis Thompson to duet badaczy, którzy stworzyli popularny współcześnie model demokracji deliberatywnej, w którego ramach przykłada się dużą wagę do kwestii pluralizmu. Autorzy charakteryzują demokrację deliberatywną przez wskazanie podstawowych cech tego ustroju takich, jak: publiczny charakter deliberacji; dostępność deliberacji dla wszystkich obywateli; to, że proces deliberacji produkuje wiążące decyzje; deliberacja ma charakter dynamiczny i dopuszcza możliwość kontynuowania dialogu. Na podstawie tych cech autorzy definiują demokrację deliberatywną jako: „formę rządów, w ramach której równi i wolni obywatele (i ich reprezentanci) uzasadniają decyzje za pomocą zasad, które są wzajemnie akceptowane i ogólnie dostępne oraz wiążące dla wszystkich obywateli, ale otwarte na wyzwania w przyszłości” (Gutmann, Thompson, 2004, s. 7). Gutmann i Thompson dookreślają deliberację przez rozważenie jej problematyki z perspektywy następujących dychotomii: instrumentalna-ekspresywna; substancjalna-proceduralna, konsesnsualna-pluralistyczna. W przypadku ostatniej dychotomii, która jest dla nas interesująca z perspektywy wywodu, autorzy opowiadają się za pluralizmem, zauważając, że rozumne różnice (reasonable differences) zawierają częściowe zrozumienie stron oraz że na niezgodzie można w bardziej adekwatny sposób budować politykę demokratyczną, niż na konsensusie niewiadomego pochodzenia. Autorzy wskazują, iż moralna niezgoda jest twórczym elementem, który zapewnia dynamikę demokracji deliberatywnej. Zwracają jednak uwagę na dwie zasady wyższego rzędu, które regulują kwestię pluralizmu: „zasadę blokowania” i ,zasadę akomodacji”. Zauważmy już w tym miejscu, że intencją autorów jest pójście w innym kierunku niż rozumny pluralizm. Nie sądzą oni bowiem, iż moralny konsensus powinien być utrzymywany sztucznymi wymaganiami narzuconymi z góry. Nie widzą konkretnych wymogów na szczeblu samej deliberacji. Nie projektują oni rozumnego pluralizmu, lecz rozumną niezgodę, zatem zasady wyższego rzędu mają charakter bardziej pierwotny. Zasada blokowania dotyczy dopuszczania tematów do agendy politycznej. Zgoda ma mieć wobec tego charakter głębszy - ma dotyczyć zgody co do tego, co jest 
przedmiotem niezgody politycznej; co jest w ogóle brane pod uwagę. Zasady blokowania odnoszą się więc do tego, co należy odrzucać jako dyskurs pozamoralny, a zasada akomodacji do tego, co należy do dyskursu demokracji deliberatywnej włączać. I w tym przypadku moglibyśmy wskazać zasadę prymarną, która łączy wszystkie wyżej wymienione - jest to zasada wzajemnego szacunku, która ma stanowić prerekwizyt demokracji deliberatywnej (2004, s. 64-65). Ponadto zasady blokowania i akomodacji dopuszczają większą zmienność dyskursu. Autorzy sięgają więc raczej do twórczości Habermasa, który podkreślał dynamiczny charakter komunikacji, niż do konsensualistycznych tez Rawlsa. Wartościowym elementem analizy jest ukazanie wielu płaszczyzn pluralizmu i znaczenia filozofii publicznej w kształtowaniu dyskursu politycznego. Autorzy wskazują bowiem, że:

„Praktykowanie cnoty wzajemnego respektu, tak jak proponujemy tutaj, spowodowałoby utworzenie szerszego rodzaju politycznego konsensusu, a co za tym idzie, rozszerzyłoby zakres tego, co nazywamy filozofią publiczną - układ moralnych zasad, na podstawie których rozumni obywatele powinni się zgoda bez względu na moralne zasady, którymi kierują się prywatnie. Taka filozofia publiczna objęłaby nie tylko zasady chroniące prawa podstawowe (takie jak niedyskryminacja) i zasady, który uzasadniają pewne procedury (takie jak zasada większości), ale również zasady, które rządzą moralnymi relacjami w publicznym życiu” (2004, s. 90-91).

Jest to zatem kolejna próba uregulowania pluralizmu racjonalności, tym razem przy zastosowaniu podstawowej zasady współżycia społecznego jako rdzenia deliberatywnego modelu demokracji.

\section{PLURALIZM RACJONALNOŚCI PRIMA FACIE I PLURALIZM RACJONALNOŚCI SENSU PROPRIO}

Wyżej wyróżniliśmy trzy rodzaje podejścia do pluralizmu: 1) racjonalność pluralizmu; 2) pluralizm racjonalności prima facie i 3) pluralizm racjonalności sensu proprio. Zauważyć należy, że przedstawione stanowiska pluralistyczne nolens volens zawierają jakiś element wykluczenia - nawet paradoksalnie wykluczając możliwość przyjęcia imparcjalizmu jako porządku demokracji deliberatywnej. W koncepcji Iris Marion Young główną zasadą, która regulowała pluralizm, była inkluzja; według Seyli Benhabib pluralizm umożliwia konstytuowanie się tożsamości opartej na różnicy. W przypadku Chantal Mouffe również istnieją stanowiska, 
które przeczą idei pluralizmu, a co za tym idzie, które nie są pożądane w sferze publicznej. Pomijając trywialną kwestię ideologii liberalnej, która dąży do zawężenia dyskursu politycznego, przeciwnikiem pluralistycznego agonizmu jest stanowisko antagonistyczne, czyli takie, które w duchu Schmittowskim postulowałoby powrót do polityczności. Amy Gutman i Dennis Thompson schodzą na głębszym poziom relacji społecznej, który warunkuje warunkowanie funkcjonowania sfery publicznej. Jest to zatem próba uzyskania autentycznego obrazu demokracji pluralistycznej przez dociekanie do głębszego wymiaru (nie)zgody politycznej.

Po przedstawieniu powyższych koncepcji pluralistycznych dochodzimy do wniosku, że w każdym z omówionych przypadków dostrzegamy przede wszystkim sprzeciw wobec imparcjalizmu. To znaczy, że według wskazanych wyżej autorów wolny pluralizm to taki, który wyklucza jego rozumność. Jest to zatem sprzeciw wobec rozumności - spory między pluralistami a imparcjalistami są sporami o to, jaka zasada będzie regulowała pluralizm. Widzimy wobec tego wyraźnie, że mamy do czynienia z pluralizmem racjonalności prima facie. Rozumiemy przez to, iż postulaty pluralizmu stanowią tu jedynie środek do celu, którym jest forsowanie różnych wizji społeczeństwa liberalnego. Sformułowanie „pluralizm racjonalności” powinno być wiązane raczej z retorycznym wymiarem demokratycznej filozofii politycznej. Żaden z przedstawicieli pluralizmu racjonalności nie opowiedziałby się za kooegzystowaniem w jednej sferze publicznej - zwłaszcza w obszarach decyzyjnych - zwolenników pluralizmu i przeciwników pluralizmu; agonistów i antagonistów; zwolenników rozumnego pluralizmu i rozumnej niezgody; demokratów i antydemokratów. Taki porządek jest niemożliwy do utrzymania na płaszczyźnie politycznej. Pluralizm racjonalności sensu proprio jest za to możliwy do zaistnienia w sferze działalności naukowej. W myśleniu, które ma miejsce w ramach akademii, gdzie taki ład reguluje się samorzutnie. Duże znaczenie ma oczywiście przypadek, podobnie jak duży wpływ na rozwój nauki mogą mieć osobiste preferencje badaczy. Jednak uznać należy, że pluralizm jest w świecie naukowym zjawiskiem naturalnym. Zauważmy, iż istnieją sytuacje, w których wolność ta zostaje zakłócona. Niech za przykład posłuży nam kontrowersja wokół publikacji The Bell Curve (Herrnstein, Murray, 1994). Autorzy badań przyjęli za cel ustalenie związku między położeniem społecznym osób w przekroju populacji a ich poziomem inteligencji oraz inteligencji z rasą. Autorzy zostali zbrukani za rasizm i szowinizm, a ich badania zostały uznane za społecznie szkodliwe. Sytuacje takie mają miejsce, gdy w sfery pluralizmu racjonalności sensu proprio wkraczają czynniki polityczne, co pociąga za sobą walkę ideologiczną, a zasadą każdej ideologii jest kierowanie się ściśle wyznaczonymi zasadami i regułami argumentacji. Imre Lakatos, kojarzony podobnie jak Paul Feyerabend, z podejściem pluralizmu 
racjonalności sensu proprio broni wolności naukowych w następujących słowach: „Problem odróżnienia nauki od pseudonauki ma poważne implikacje również dla instytucjonalizacji krytyki [...] Nowe liberalne organizacje rządowe Zachodu również korzystają z prawa do odmowy wolności słowa temu, co uważają za pseudonaukę, jak to widzieliśmy w przypadku nad związkami rasy i inteligencji” (Lakatos, 1995, s. 361-362). Deklaruje on ponadto, że: „Moim zdaniem nauka jako taka nie ponosi społecznej odpowiedzialności. Moim zdaniem to społeczeństwo ponosi odpowiedzialność - odpowiada za zachowanie niezależnej, apolitycznej tradycji naukowej i za to, aby nauka mogła szukać prawdy w sposób określony wyłącznie przez jej wewnętrzne życie” (1995, s. 366).

\section{PODSUMOWANIE}

W toku powyższego wywodu przedstawiliśmy napięcia, jakie występują w ramach sporów między imparcjalistami a pluralistami w ramach teorii demokracji deliberatywnej. Głównym przedmiotem tego sporu jest rola rozumu w stosunku do zjawiska pluralizmu. Celem uporządkowania badanej materii wyróżniliśmy trzy możliwe postacie pluralizmu: racjonalność pluralizmu, pluralizm racjonalności prima facie i pluralizm racjonalności sensu proprio. Po pierwsze wykazaliśmy relacje racjonalności pluralizmu i pluralizmu racjonalności prima facie; po drugie, zidentyfikowaliśmy dyrektywy, które obowiązują w ramach podejścia, które w imię zwalczania pryncypium rozumu w deliberacji proponuje inne konkretne i równie apodyktyczne zasady porządkujące; po trzecie, zarysowaliśmy typ pluralizmu, który najbardziej zbliża się do pluralizmu czystego (pozbawionego zasady porządkującej) i porównaliśmy go z pluralizmem racjonalności prima facie, przez co wykazaliśmy niepełność tego drugiego.

\section{Bibliografia}

Benhabib, S. (2002). The Claims of Culture. Equality and Diversity in the Global Era. Oxford: Princeton University Press.

Benhabib, S. (red.) (1996). Democracy and Difference. Contesting the Boundaries of the Political. Princeton: Princeton University Press.

Dahl, R. (1999). Demokracja i jej krytycy. Kraków: Społeczny Instytut Wydawniczy Znak. Derrida, J. (1999). Chora. Warszawa: Wydawnictwo KR.

Ferguson, A., Nagel, M. (red.) (2009). Dancing with Iris. The Philosophy of Iris Marion Young. Oxford: Oxford University Press.

Feyerabend, P.K. (1996). Przeciw metodzie. Wrocław: Wydawnictwo Siedmiogród. 
Gutmann, A., Thompson, D. (1996). Democracy and Disagreement. Cambridge Mass: Belknap Press of Harvard University Press.

Gutmann, A., Thompson D. (2004). Why deliberative democracy? Princeton Oxford: Princeton University Press.

Herrnstein, R.J., Murray, Ch. (1994). The Bell Curve. Inteligence and Class Structure in American Life. Free Press.

Laclau, E., Mouffe Ch. (1985). Hegemony and Socialist Strategy. Towards a Radical Democratic Politics. London New York: Verso.

Lakatos, I. (1995). Pisma z filozofii nauk empirycznych. Warszawa: Wydawnictwo Naukowe PWN.

Mouffe, Ch. (2013). Agonistics. Thinking The World Politically. London New York: Verso. Mouffe, Ch. (2005). On the Political. London New York: Routledge.

Mouffe, Ch. (2000). The Democratic Paradox. London New York: Verso.

Mouffe, Ch. (1999). Deliberative Democracy or Agonistic Pluralism? Social Research, 3(66), s. 745-758.

Mouffe, Ch. (red.) (1992). Dimensions of Radical Democracy. London New York: Verso.

Schmitt, C. (2010). Etyka państwowa i państwo pluralistyczne. Kronos, 2(13), s. 71-81.

Schmitt, C. (2000). Teologia polityczna i inne pisma. Kraków: Wydawnictwo Znak.

Szahaj, A. (2000). Jednostka czy wspólnota? Spór liberałów z komunitarystami a „sprawa polska”. Warszawa: Fundacja Aletheia.

Tischner, J. (2011). Myślenie według wartości. Kraków: Wydawnictwo Znak.

Tischner, J. (1993). Nieszczęsny dar wolności. Kraków: Wydawnictwo Znak.

Vattimo, G. (2006). Społeczeństwo przejrzyste. Wrocław: Wydawnictwo Naukowe Dolnośląskiej Szkoły Wyższej Edukacji TWP we Wrocławiu.

Young, I.M. (2000). Inclusion and Democracy. Oxford New York: Oxford University Press. Young, I.M. (1990). Justice and Politics of Difference. Princeton: Princeton University Press. 